\title{
Perspective of Problems and Countermeasures by the Analysis of the Collection Data on the Personal Income Tax Collection and Administration of High Income Groups
}

\author{
Chunyan Pan \\ School of Management, Jinan University, Guangzhou, China \\ Email: 313600531@qq.com
}

Received 22 September 2015; accepted 23 October 2015; published 26 October 2015

Copyright (C) 2015 by author and Scientific Research Publishing Inc.

This work is licensed under the Creative Commons Attribution International License (CC BY). http://creativecommons.org/licenses/by/4.0/

(c) (i) Open Access

\begin{abstract}
In recent years, the collection and administration of personal income tax of high income groups have always been the emphasis and difficulty of the tax authority. This article analyzes the personal income tax collection and management data of GZ city $Y$ area local taxation bureau, and finds that the current tax authorities on the personal income tax levy management have some problems, such as the individual income tax of the total amount of wages and salaries accounts for a large proportion of the total individual income tax, and it is difficult to regulate the individual business production and operation income and labor remuneration income, and the number of foreign individuals hidden income rise, etc. The working practice is also connected to discuss and analyze the above problems, putting forward many measures to establish and improve the system of tax assessment, building effective network for assistance and protection of tax, strengthening the collection and management of various income taxes, establishing individual tax registration system and personal bank account system, reinforcing audit and penalties and so on.
\end{abstract}

\section{Keywords}

Collection and Management Data, High Income, Individual Income Tax

\section{Introduction}

In recent years, with the rapid development of economy in our country, urban and rural residents' income level

How to cite this paper: Pan, C.Y. (2015) Perspective of Problems and Countermeasures by the Analysis of the Collection Data on the Personal Income Tax Collection and Administration of High Income Groups. Open Journal of Social Sciences, $\mathbf{3}$, 124-133. http://dx.doi.org/10.4236/jss.2015.310018 
has enhanced unceasingly, and the contradiction of personal income gap has been increasingly prominent. Strengthening the collection and administration of personal income tax of high income groups is the basic requirement to narrow the gap between the rich and the poor and build a harmonious society, and is the inevitable trend for the local tax authority to effectively organize the tax revenue, promoting scientific and fine management.

\section{High Income Groups Defined}

Under the reality condition of economic development, people's income growth, it is difficult to draw an income standard to determine whether individuals belong to high income groups. But by refer to the social average wage level indicators, combining with the daily administration work experience as well as knowing the high income group's tax [1], we can preliminarily determine the following individual personal income tax as the key monitoring scope of high-income groups: 1) The foreigners, overseas Chinese and Hong Kong, Macao and Taiwan compatriots that worked in our city; 2) Foreigners, overseas Chinese and Hong Kong, Macao and Taiwan compatriots that offer services in our city in the name of the foreign companies; 3) Foreigners, overseas Chinese and Hong Kong, Macao and Taiwan compatriots that provide professional services as independent personal identity; 4) Coaches and athletes, actors, fashion models, TV hosts; 5) Employees' lawyers, Certified Public Accountants (Certified tax agents), stock traders, agents that engaged in literature and art, sports, and economic activity; 6) Above district-level medical institutions or experts that above social associate chief physician and associate professor of medical institutions, and experts that above the professors of Higher Institutions; 7) The expatriate staff; 8) The legal representative and financial director of high income industry in our city; 9) Individuals that get two or more personal wages and salaries; 10) Building contractors; 11) Private limited liability company's investors (shareholders) with last year's business (sales) income reached 10 million Yuan and over; 12) Individual business owners, sole proprietorship, the partnership enterprise investors, investment lawyers that with last year's business (sales) income reached 5 million Yuan and above; 13) The other key taxpayers that are determined by the tax authorities.

\section{The Importance of Strengthening Collection and Administration of High Income Groups}

\subsection{Strengthening Collection and Administration of the High Income Groups Is the Important Means to Promote Social Justice, Safeguard Social Harmony [2]}

The party's Fifth Plenary Session of the $17^{\text {th }}$ Central Committee passed "the Twelfth Five-year Plan for national economic and social development suggestion made by the Central Committee of CCP" required "Strengthen tax adjustment of income distribution, effectively regulate excessively high incomes". Fourth meeting of the $11^{\text {th }}$ National People's Congress approved the law of "the People's Republic of China on the Twelfth Five-year Plan for national economic and social development program" offered to "Improve the personal income tax collection and administration mechanism", "Enhance the tax regulation on high earners". Do a good job on high income individual income tax collection and administration is of great significance for the effective use of adjusting income distribution function, promote social equity, harmony and stability.

\subsection{Strengthening Collection and Administration of the High Income Groups Is an Important Approach to Ensure Tax Revenue Growth}

Personal income tax is one of the three main taxes in local taxation bureau. In recent years, with the development of the economy, the increase of the residents' income, individual income tax are now a growing proportion of the total amount of land tax warehousing, has become an important part of land tax revenue.

On $30^{\text {th }}$ June 2011, the National People's Congress voted on amending the decision of the individual income tax law, monthly wages and salaries revenue minus 3500 Yuan, the balance belongs to the taxable income; income from wages and salaries are still fit for excess progressive tax rate, tax rate is from $3 \%$ to $45 \%$ [3]. The individual income tax collection will be significantly reduced by the new individual income tax law; only by strengthening tax collection and administration of the high income groups, the individual income tax-as the main tax status can be ensured, so as to ensure tax revenue continues to grow. 


\section{Analysis of the Tax Collection and Management of the High-Income Groups from the Perspective of Individual Income Tax Collection and Management Data}

GZ city $\mathrm{Y}$ area as the administrative, commercial, financial and cultural centre of GZ city, attracting a large number of enterprises and talents, is one of high income group concentration areas in GZ city. And GZ city Y area local taxation bureau as the "First Good Local Taxation Bureau" of GZ municipal, whose tax scale is always at the forefront of GZ city, is one of the most influential and representative district bureau in GZ city. So it has certain representativeness to analyze the data of individual income tax collection and administration of this district.

\subsection{The Individual Income Tax of High Income Groups Is of Low Share of the Total Amount of Individual Income Tax}

Seen from Table 1, people with monthly income below 7000 Yuan and over 22,000 Yuan, their proportion of the payment of individual income tax reduced year by year, people with monthly income between 7000 Yuan to 22,000 , their proportion of the payment of individual income tax increased year by year, and ultimately form of little at both ends but large in the middle "olive shape" distribution, the individual income tax is more and more rely on the middle class to support, however, individual income tax of high earners accounted for a small proportion of the total amount of income tax.

Combined with Table 2 we can see that, in 2010, the declaration people of monthly income over 22,000 Yuan is 420,000 Yuan, accounting for $1.04 \%$ of the total people, and in 2013 the proportion increased to $2.05 \%$, increased $100 \%$ compare to 2010 , while the monthly income between 7000 Yuan to 22,000 Yuan, the proportion only year-on-year grow $80 \%$; but in 2013, the monthly income over 22,000 Yuan, the individual income tax accounted for the total individual income tax proportion only increased 3.95\% compare to 2010; That is to say, the number of high income group did not result in the increase on their pay income tax with the same rate. Individual income tax uses extra progressive tax rate, the higher the income tax rate is, the greater the tax burden is; under normal circumstances, the proportion of the number of high income groups accounted for the total number doubled, the proportion of its tax pay revenue accounted for the total revenue should be doubled or more than doubled. The above analysis shows that the tax revenue growth of the high income groups with wages and salaries increased out of the proportion to the growth of the number of higher income groups. In practical work, we found that the tax pay consciousness of the higher income groups was not strong, tax evasion and tax avoidance means were diversified, and the difficult local tax authority supervision and so on, all caused the tax evasion.

Table 1. The proportion of the individual income tax of various income groups to the total amount of individual income tax.

\begin{tabular}{|c|c|c|c|c|}
\hline Monthly Income & 2010 & 2011 & 2012 & 2013 \\
\hline Below 7000 Yuan & $39.54 \%$ & $32.62 \%$ & $30.15 \%$ & $28.97 \%$ \\
\hline 7000 Yuan to 22,000 Yuan & $34.63 \%$ & $35.86 \%$ & $40.55 \%$ & $41.25 \%$ \\
\hline Above 22,000 Yuan & $25.83 \%$ & $31.52 \%$ & $29.30 \%$ & $29.78 \%$ \\
\hline
\end{tabular}

Notes: The data of this article all come from Y district local taxation bureau TRAS system.

Table 2. The number change of the individual income tax of various income groups.

\begin{tabular}{|c|c|c|c|c|}
\hline Monthly Income Year & 2010 & 2011 & 2012 & 2013 \\
\hline Below 7000 Yuan & 3606 & 3868 & 3501 & 3958 \\
\hline 7000 Yuan to 22,000 Yuan & 376 & 497 & 557 & 677 \\
\hline Above 22,000 Yuan & 42 & 68 & 79 & 97 \\
\hline Summary & 4024 & 4433 & 4137 & 4732 \\
\hline
\end{tabular}

Notes: The person-time of this table and Table 4 refers to the declare times of the whole year, not only refers to the number of people. 


\subsection{Wages and Salaries Income Individual Income Tax Ratio Is on the High Side, Other Income Individual Income Tax Regulation Is Difficult to Supervise}

Table 3 shows that in 2013, Y area wages and salaries income individual income tax accounted for $80.36 \%$ of the total amount of income tax, while the production and business operation income of the individual business accounted for only $3.87 \%$, the second is the labor remuneration income accounted for $3.87 \%$, interests, dividends, dividend income accounted for $3.50 \%$, contingent income accounted for $3.37 \%$, other incomes are not more than $3 \%$, and even some incomes close to zero. Wages and salaries income become the main source of individual income tax, while the other income proportion is very limited. In recent years, GZ city has diversified economic development; the form of payment is also diversified. And the above data shows that wages and salaries income accounted for $80 \%$ of the total amount of income tax, other income proportion is very small, it does not adapt with the overall trend of GZ city economic development. In practice, tax authorities strictly implement all members' declaration and "two-way" declaration systems, regulation of individual income tax of wages and salaries income is basically in place. While for the income other than wages and salaries, there are different levels of regulatory loopholes, many high earners are more and more tend to use other forms to evade taxes, such as a labor income is divided into several portions, make the tax loss.

In addition, from 2010 to 2013, the proportion of the wages and salaries income individual income tax accounted for the total amount of income tax rose, from $76 \%$ in 2010 to $80.36 \%$. The production and operation income of the individual business, and interest, dividends, dividend income are declining; which shows that wages and salaries income individual income tax "alone big" trend is growing, other than wages and salaries income tax collection and administration urgently needs to be strengthened.

\subsection{The Foreigners Individual Income Tax Hidden Income Situation Is Grim}

In recent years, foreigners came to work in GZ city $\mathrm{Y}$ area increased year by year, 87,000 person-time from 2010 increased to 148,700 in 2013, an increase of 70.59\%. And the payment of wages and salaries individual income tax increased from 106.58 million Yuan in 2010 to 140.62 million Yuan in 2013, the growth is only $31.94 \%$, person-time growth is about 2 times increased than the wages and salaries tax individual income tax, that is to say, the growth of the number of foreigners does not bring the corresponding percentage of revenue growth. In recent years, GZ city Y foreigners increased year by year, as the individual income tax of foreign nationals is difficult to regulate, foreigners' tax assessment is difficult to effectively carry out, low illegal costs and

Table 3. 2013 year the subtitle tax revenue statement of individual income tax.

\begin{tabular}{|c|c|c|c|c|}
\hline & 2010 Year & 2011 Year & 2012 Year & 2013 Year \\
\hline 1. Wages and salaries income & $76.00 \%$ & $80.58 \%$ & $79.96 \%$ & $80.36 \%$ \\
\hline $\begin{array}{l}\text { 2. The production and business operation income } \\
\text { of the individual business }\end{array}$ & $5.03 \%$ & $4.65 \%$ & $4.87 \%$ & $3.87 \%$ \\
\hline $\begin{array}{l}\text { 3. Income from contractual or leasing operations } \\
\text { to enterprises or institutions }\end{array}$ & $0.14 \%$ & $0.08 \%$ & $0.06 \%$ & $0.04 \%$ \\
\hline 4. Labor remuneration income & $3.85 \%$ & $3.67 \%$ & $3.83 \%$ & $3.87 \%$ \\
\hline 5. Income from authors remuneration & $0.15 \%$ & $0.16 \%$ & $0.18 \%$ & $0.18 \%$ \\
\hline 6 . Income from royalties & $0.04 \%$ & $0.02 \%$ & $0.03 \%$ & $0.08 \%$ \\
\hline 7. Interest Dividend and Bonus Income & $7.04 \%$ & $5.58 \%$ & $3.43 \%$ & $3.50 \%$ \\
\hline 8. Income from lease of property & $0.83 \%$ & $0.82 \%$ & $0.80 \%$ & $0.78 \%$ \\
\hline 9. Income from transfer of property & $2.54 \%$ & $1.14 \%$ & $2.30 \%$ & $2.15 \%$ \\
\hline 10. Accidental income & $3.24 \%$ & $2.60 \%$ & $3.36 \%$ & $3.37 \%$ \\
\hline 11. Other income & $1.06 \%$ & $0.60 \%$ & $1.13 \%$ & $1.73 \%$ \\
\hline 12. Taxes overdue payment fines and other fines & $0.10 \%$ & $0.08 \%$ & $0.05 \%$ & $0.07 \%$ \\
\hline
\end{tabular}


Table 4. Statement of declaration person-time changes in the various income range of foreigners (expect Hong Kong, Macao and Taiwan compatriots).

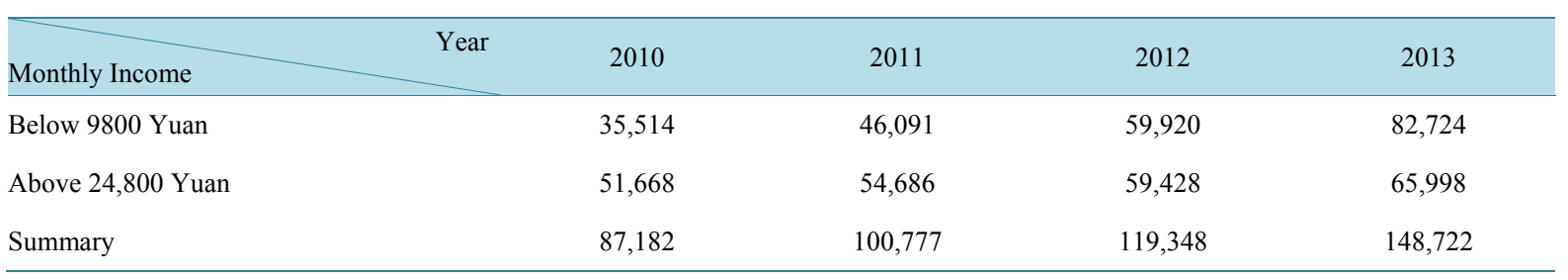

Unit: ten thousand per time.

other reasons, many foreigners began to understate and omission of income to evade taxes.

Seen from Figure 1, the proportion of the number of foreign people (with the exception of Hong Kong, Macao and Taiwan compatriots) monthly revenue below 9800 Yuan accounts for the total number of foreign people (except Hong Kong, Macao and Taiwan compatriots) increased year by year, that is to say, foreigners declare wages and salaries income decreased year by year. This shows that to some extent, the tendency of foreigners hidden income situation increased year by year.

\section{The Main Factors Influencing the Individual Income Tax Collection and Administration of High Income Groups}

In recent years, GZ municipal local taxation bureau has made a lot of beneficial explorations in the individual income tax collection and administration of high-income groups. Such as fully implementing the individual income tax all members declaration and "two-way" declaration system, improving the level of the whole income tax declaration, income tax self-declaration number 120,000 also increased year by year; analysis and comparison of the wages and salaries income of enterprise income tax expenses and individual income tax revenue, mending a large amount of taxes; With the comparison of the ministry of commerce and industry information, strengthening the non-listed company's equity transfer, use the present comprehensive revenue system mending a large number of taxes; Advancing the individual commission basis work, and so on. But the individual income tax levy management still exist many problems to be cracked.

\subsection{Individual Income Diversification, Recessivation Make It Difficult to Regulate}

In our market economy system, there are lots of individual income sources and methods, and are conceal and complex. Such as part-time income, property transfer income and property rental income, and so on, these incomes are relatively decentralized, and concealed. In practical work, the tax authority mainly adopts the method of source withhold and individual voluntary declaration to supervise personal income; however, now the taxpayers' tax consciousness is generally not high, rely on the source withholding can effectively supervise the wages and salaries income, and other a large quantities of income that are not paid by the unit, labor remuneration, lease of property, property transfer income, and individual production and operation income of individual business with imperfect accounting cannot be effectively supervised.

\subsection{Assist and Protect Tax System Fails to Work Effectively [4]}

In recent years, GZ city has been committed to establish an assist and protecting network to cover the whole society. In Year 2009, after the GZ city e-government data center management system (hereinafter referred to as "Comprehensive Revenue Platform") established, till December 2010, a total of 14 government functional departments join the platform to exchange tax-related data, the establishment of the platform opens an important step to build the tax-related information exchange system and joint action system among government departments. But Comprehensive Revenue Platform, on the content and exchange means, lack of legal protection, and the department communication difficulty result in data quality unguaranteed, at present the Comprehensive Revenue Platform has not played its proper role.

GZ city local taxation bureau emphasized individual commission levy work, and has achieved remarkable success at present. But individual commission basis lack of institutional guarantee in funds safeguard work, department coordination, resource integration, etc, and the individual commission levy work focused on the man- 


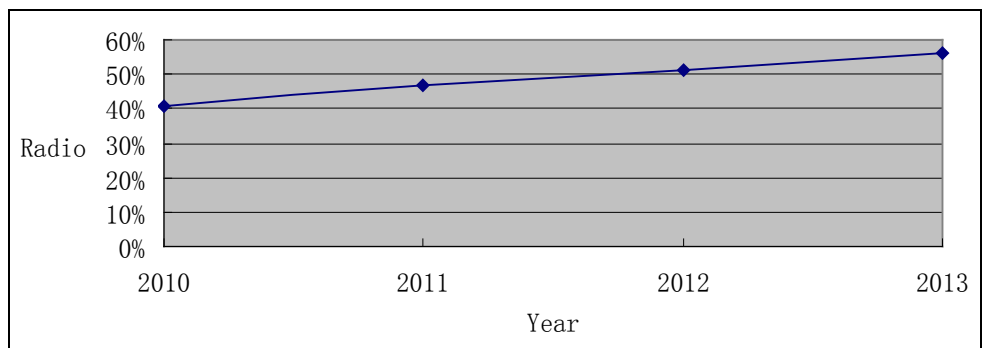

Figure 1. The proportion variation of the number of foreign people (with the exception of Hong Kong, Macao and Taiwan compatriots) with monthly revenue below 9800 Yuan.

agement of the individual business, for the other taxpayers and taxable income can not be supervised, its contribution to the construction of the assist and protect the whole network is still limited.

\subsection{The Collection and Management of the Individual Income Tax Lacks the Support of Powerful Regulatory System}

\subsubsection{It Is Difficult for Tax Administrators to Do An Elaborate Management in the Revenue of the Individual Income Tax}

Tax administrators have numerous works to handle, so that they can hardly make an elaborate management in the revenue. Taking Y District of GZ City as an example, there are over 440 tax administrators per capita in Local Tax Bureau in Y District and several tax administers in a part of the development administer over 5000 individual businesses. Tax administrators need to handle some affairs such as the examination and approval of documents, tax consultation, investigation, social insurance business and so on. In addition, they have to do some business training, tax analysis and other works so that they have no energy to strength the collection and management of the individual income tax.

\subsubsection{Tax Assessment of the Individual Income Tax Has Not Been Implemented Effectively}

Tax assessment of the individual income tax is a difficult point in the collection and management of the individual income tax. Because the individual income tax is a sensitive thing that related to our personal interests and it will arouse some people's resistance. Furthermore, there are many difficulties in the inspection and it hasn't an effective way to verify those conditions such as individual gains in many aspects, settlement of cash income foreign income. However, grass-roots tax authorities do not have enough energy and also lack of scientific and reasonable methods and the indispensible information to carry out the individual income tax check and tax assessment.

\subsection{Big Challenge in Management of Foreign Nationals}

\subsubsection{Foreign Nationals Have both Domestic and Overseas Income So That It Is Hard to Revenue in Full}

Generally speaking, for those who are working in the enterprises in China, their individual income tax can be withheld mainly. However, there are some foreigners working in China received a small part of the salary and most of their wages or salaries and bonuses are all get from their overseas company. So this condition is hard to handle and we can hardly impose full amount of the tax. Because of inefficient information exchange, the Grassroots Tax Department cannot make effective use of those information resources.

\subsubsection{Individual Income Tax Withholding to Those Foreigners Who Are Providing a Temporary Work in China Is Hard to Monitor}

With the depth of the reform and opening up, business exchanges between mainland enterprises and overseas enterprises are increasing and there are more and more foreigners come to China to engage in the survey and design, equipment installation and technical guidance. Because engaging in machinery and equipment installation or independent personal services in different regions of China, those kinds of foreigners are a flexible in area and time so that their working time is hard to know. Those foreigners who provided technical consultation, su- 
pervision and methods of managements for a short time generally will not stay in China more than 183 days. For their entry time is short, basically their wages are often paid by the dispatched overseas company rather than the mainland enterprises that they served for. So they cannot be regarded as taxpayers in China. Therefore, to a great extent, whether taxes will be reported into our national treasury in time or not depends on taxpayers' positivity. Because of the lack of effective methods in the collection and management, the negligence of Tax Department will easily cause omission in tax collection.

\subsection{Insufficiencies in Tax Inspection and Punishment of Taxations}

Because of limited manpower in inspection, so for a long time, the purpose of inspection emphasizes to finish the tax target by urgent inspection and it is rare to do inspections in individuals. Inspection Bureau often picks some large profitable enterprises to inspect. Once they found individual's evasion of tax, they will just punish the taxpayers which have not enough deterrence to average men [5]. Moreover, although Criminal Law and Tax Administration Law has a rule that if he or she doesn't make tax declaration, unpaid or paid less tax, the competent tax department shall pursue the payment of the tax evaded and impose a fine of amount of $50 \%$ to five times of the amount of tax evaded. As for the administration of individual income taxation, tax departments mainly adopted penalties of paying an overdue tax which is not a serious one to tax dodgers. Law breakers did not get their just punishment which encourages the tax evasion.

\subsection{High-Income Groups Have Poor Awareness of Paying Taxes}

At present, most of the residents have poor awareness of tax payment. They either take tax as a monster or ignore the importance and seriousness of it. There are following reasons. Firstly, the body of taxpayer is an enterprise as legal person for a long time in our country and it rarely involves a natural person. Moreover, our government imposes a minimum wage system, so taxpayers' awareness of paying tax is not deep within people's mind. Secondly, people's understanding about taxation is superficial. Most of the residents didn't realize that their life has a close connection with taxation. To some extent, some people's awareness about taxation has been changed a little by with the propaganda of taxation, but we still have to make more efforts to strengthen their awareness of paying tax. Thirdly, the publicity of taxation is still not enough. Currently, publicity of taxation does not involve many aspects and it is simple in mean. For individual business and other groups who need to be popularized the knowledge of tax laws, tax government did not find an efficient way to promote the laws and explain the bug about income from labor service payment.

\section{Suggestions about Further Strength of the Collection and Management of Taxation in High-Income Groups}

\subsection{Establishing and Perfecting Tax Evaluation System}

\subsubsection{Setting up Institutions of Tax Evaluation in Every Bureau and City}

Tax evaluation institution must fix work thinking, complete the structure of institution and pick up eminent people who are proficient in tax evaluation, tax business and accounting knowledge. It must be sure that executive in Bureau is directly leading the evaluation. And it should give priority to the evaluation of the individual income tax on high-income groups in order to avoid tax evasion on them.

\subsubsection{Strengthening the Training of Tax Evaluators}

Tax assessment is professional, so it needs evaluators with highly abilities in learning and research. We can establish case base mechanism with tertiary structures which including two offices of case base in City Bureau and District Bureau and different department. So we can compile a book of classic case. For tax evaluators, they need to study carefully to the compiled case base and discuss regularly for their work in future.

\subsubsection{Setting up Tax Evaluation Check Mechanism}

We should develop tax evaluation as a standard that can pick excellent evaluators out. We should set up tworank evaluation mechanism that their work directly is hooked up with their promotion and bonuses and form an effective incentive system. 


\subsection{Establishing a Network Aiming in Helping and Protecting Taxation}

In order to carry on complementary and effective inspection to the individual income tax on high-income groups, a network about helping and protecting taxation in the whole society should be established, and then professional management in tax department, assistance and protection of tax in social sectors and in the masses has gradually formed.

\subsubsection{Effective Utilization of Comprehensive Platform on Administration of Tax in GZ City}

Firstly, GZ City needs to improve its states in comprehensive platform on administration of tax and should realize the importance of the platform and attach great importance to its building. Municipal government should play a dominant role on enacting methods, defining rights for every department, confirming responsible men who provide information exchanges and setting up regularly meeting system, fund security and incentive mechanism, thus it enables most effective use of the platform in GZ City.

\subsubsection{Build the Network to Protect the Tax in District}

People should study to establish a tax system that becomes more extensive coverage and higher degree of social integration on the basis of the network of individual clients. First of all, we should recommended that to establish a tax system that leading by government and work closely with other departments. And then to establish a tax group that leading by district government and their leaders, this group is responsible for the organization, management, coordination, supervision and guidance of the tax work in district. Hold the meetings regularly, and get together to coordinate the work of tax protection. Also people should build a bureau in the streets to protect the tax, strength the organization and management of the street and the district of tax protection. Besides, to formulate scientific and feasible scheme of the tax protection, to determine all the responsibility of each department in the form of documents, also, people should establish a working meeting system, work coordinate mechanism, information sharing mechanism, funs safeguard and the incentive mechanism, inspections regularly and impose the censorship in order to ensure daily work carried out effectively.

\subsection{Enhancing the Collection and Management of Income from Production, Operation Derived by Industrial and Commercial Households and Their Individual Income Tax}

\subsubsection{Enhancing the Collection and Management of Income from Production, Operation Derived by} Industrial and Commercial Households and Their Individual Income Tax

Firstly, as for those individual businesses who run a moderately large-scale company and who meet eligibility to set up accounts, tax department should impose their individual income tax according to the rule of tax revenue. If those individual businesses have some mistake in this account, tax department will have rights to punish their misconduct and set a high standard to their turnover as a punishment. For another individual business whose account cannot be check accurately, the tax department should use some scientific methods such as Parameter management method, Six cost method and Incremental method base to avoid any possible tax evasion and check and ratify their turnover in accordance with the types of individual businesses.

\subsubsection{Further Strengthen the Collection and Management of Income from Remuneration for Personal Services}

Firstly, tax department should strengthen publicity so that taxpayers will know the difference between labor income and salaries and get acknowledge with the procedures if they want to apply for a qualification of administrations on behalf of the tax authorities on remuneration for personal services. And those companies can find right way to declare their individual income tax. Secondly, taxpayers whose income received from two aspects should be paid much attention to. Some illegal behaviors such as turnover tax evasion and obscure between income from wages and salaries and income from remuneration of personal service should be resolutely avoided. Those taxpayers also should be given a severer punishment.

\subsubsection{Must Strengthen the Inspection of Interest, Dividends, Bonuses and Other Income Tax}

Firstly, tax department should enhance withholding at source. We should keep monitoring and inspecting regularly in auction market, the market of painting and calligraphy, antique and philatelic items, listed companies, shareholders, security companies and second-hand housing transaction. Secondly, we should implement State 
General Tax Bureau's stipulation to reinforce the administration of tax revenue of high-income groups. And we should strengthen our power of collection and management of the tax on the transfer of ownership, stock appreciation rights and restricted ballot.

\subsection{Strength the Supervision of Individual Income Tax of Foreign People}

\subsubsection{Management of Electronic Tax Filing for Foreign Personnel}

We suggest to carry out the administration of the entry and exit of foreigner's tax registration management approach, and to make clear the producers of the foreigners to handle the tax registration and to undertake the legal liabilities. On this basis, firstly, to focus on the registration information provided by foreigners, along with the help of social comprehensive tax power. Secondly, to manage the foreigners from the sources based on some information provided by the public security, labor and other departments. At the same time, people should establish the tax archives of foreigners, and to implement the policy of foreigners called "one person, one file". In addition, people should master the number, nationality, companies which hire foreigners, position, the entry and exit time, the declared income of foreigners and other information about them.

\subsubsection{Improve Foreign Personnel to Pay the Income of Foreign Intelligence Investigation System}

If people want to change the state of passive acceptance of intelligence, and to provide tax information to each other actively, the recommendation is that to build exchange notes mail among the head office, province bureau, city bureau and district bureau as soon as possible. Therefore, the intelligence transmission becomes more and more smoothly and quickly, so that can improve the efficiency of information work. In addition, people should set up a specialized agency to verify the tax of foreigners.

\subsubsection{Strengthen the Tax Assessment of Foreigners}

People should strengthen the tax assessment of foreigners, especially, people should focus on the senior management in the multi-national corporation. All the inspections should be strictly in accordance with the tax assessment guidelines for foreigners that formulate by the GZ council, and then to carry out the interview questions. Those tallying with the stipulated conditions shall be confirmed. And people should curb the foreigners behavior of tax evasion and tax avoidance resolutely.

\subsection{Learning Lessons from Foreign Advanced Management Experience}

\subsubsection{Based on the Unified Tax Number, and Strengthen the Management of Tax Sources}

People can learn from the experience of Australia that [6] develop a strict personal tax registration system and personal bank account system. People must establish a tax ID system in the country, that is to say, it have to establish a permanent tax number for every citizen who achieve the legal age, this number can be consistent with the identity card number. Even after the cancellation number is still the original tax registration, this can effectively block the taxpayer by makeover in order to escape from the original tax loopholes. Tax number is widely used, both personal income and expenditure information under this number [7], and can near-line storage in the country through bank accounts. In addition, this tax number can be used for the payment of social insurance, pension and medical insurance, and payment of unemployment benefits and minimum living security [8]. At the same time, people should establish personal income tax data processing center headquarters both in the State Administration of Taxation and the people's Bank of China, while also establish data processing center in the provinces, autonomous regions, municipalities directly under the state planning, and there should establish a data processing center division. The local tax authority should also determine the specific measures to coordinate and communicate in the system, in order to realize the information sharing truly and avoid the tendency to "fighting each other" [9]. The tax authority can processing centralized through the computer network when connected with the bank, it is convenient and accurate to grasp the income of the taxpayer so that every income of taxpayer is under the direct control of the tax authority, then it can monitor the individual income tax effectively [10]. At the same time, it stipulate that the employer pays the employee's income by means of transfer; individuals to open an account in the bank with the code of tax registration; if personal income do not present tax registration code and tax payment certification, the tax withholding by a certain proportion, while the interest and bonus withhold on the basis of the highest marginal tax rate in pre tax. That is to say, all these measures are designed to encourage taxpayers to carry out tax registration, obtain tax code and pay taxes in the tax authorities. 


\subsubsection{Increasing Audit and Penalties [11]}

In America, the tax authorities have implemented a strict auditing system, which accounts for about one percent to two percent of the total number of the reporting forms of audit report, and high earners are the focus of the audit object. Once they are found to tax evasion, they may face severe tax penalties and even prison. Therefore, we should learn from the practice of the United States that inspection departments should draw a certain proportion of high earners to carry out tax inspection, and also should give severe penalties for individuals who are malicious to tax evasion. When necessary we should exposed some of the individuals who is in the most serious situation by media in order to improve the cost of tax evasion of high earners and improve the degree of tax compliance, thus to prevent the loss of personal income tax of high income groups.

\section{Conclusion}

Through the above series of analyses and researches, it is hoped to provide some references for GZ city to strengthen the collection and administration of individual income tax, so as to improve the quality and level of tax collection and management, and regulate the tax order.

\section{References}

[1] Xia, H.W. (2013) Study on the Reform of China's Individual Income Tax System. Ministry of Finance, Beijing.

[2] Zhang, Q. (2013) Study on the Personal Income Tax Rate in China. Ministry of Finance, Beijing.

[3] Meng, L.J. (2011) The Experience of Individual Income Tax System in America and Its Enlightenment to China. China Securities and Futures, 8, 75.

[4] Feng, J. (2013) Enlightenment of the American Tax System Reform to China. Financial Research, 12, 87-89.

[5] Yao, G.F. (2014) The Difference between China and the United States Individual Income Tax Levy. Era Finance, 2, 11.

[6] Wang, T.X. and Ying, X.P. (2012) The Main Problems of Current Tax System in China. Economic Research Reference, 24, 24.

[7] Wang, Y.L. (2007) Comparative Study of Individual Income Tax System in China and Australia. Sichuan University, Chengdu.

[8] Hu, S.W. (2006) The Structure, Fairness and Harmony in the Adjustment of the Tax System. Finance and Economy, 10, 6-11.

[9] Ma, X.H. (2005) Comparative Study on Personal Income Tax-Take Australia and China as Sample. Dongbei University of Finance and Economics, Dalian.

[10] Jin, G.Y. (2007) Some Thoughts on the Reform of Personal Income Tax. Journal of Guangdong Radio \& TV University, 2, 80-82.

[11] Chen, J. (2011) Enlightenment from the Reform of Personal Income Tax in Australia. Journal of Guangzhou University of Education, 2, 32-35. 